Scientific Journal. ISSN 2595-9433

Volume 3, Number 2, Article n. 1, July/December

D.O.I. http://dx.doi.org/10.35418/2526-4117/v3n2a1

Received: 02/01/2021 - Accepted: 03/27/2021

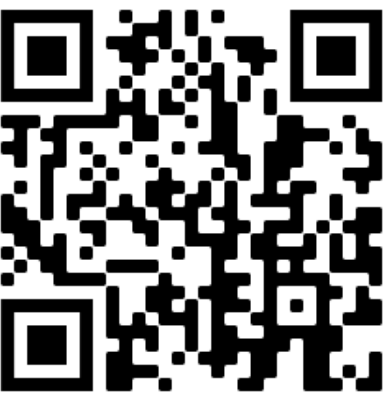

\title{
IS IT POSSIBLE TO OBTAIN SHORT CYCLE COMMON BEAN (Phaseolus Vulgaris L.) LINES WITH GRAIN YIELD SIMILAR TO NORMAL CYCLE LINES?
}

(D) Thais Lima Marques ${ }^{1}$, (D) Ângela de Fátima Barbosa Abreu², (D) Magno Antonio Patto Ramalho ${ }^{3}$

\author{
1 Department of Biology, Universidade Federal de Lavras, Lavras, Brazil; \\ 2 Retired researcher from Empresa Brasileira de Pesquisa Agropecuária (EMBRAPA), \\ Lavras, Brazil; \\ 3 Retired professor from Universidade Federal de Lavras, Lavras, Brazil. \\ * Corresponding author: Thais Lima Marques (limamarques.thais@gmail.com).
}

\begin{abstract}
The cycle of the common bean crop is shorter than that of other species. Nevertheless, in Brazil, researchers have been attempting to shorten the cycle even more to allow three crops a year and obtain greater flexibility in crop management. The aim of this study was to investigate the viability of selecting lines with a shorter cycle and that have good grain yield coming from the same segregating population. To that end, crosses were made between a short cycle and normal cycle cultivars. In the $\mathrm{F}_{2}$ and $\mathrm{F}_{2: 3}$ generations, progenies were separated into two groups based on short or normal cycle. After that, the progenies selected were evaluated in the $F_{2: 4}$ and $F_{2: 5}$ generations for grain yield, cycle, and yield per day. The mean of the short cycle progenies was 15\% lower for grain yield and 10\% lower in yield per day in relation to the normal cycle progenies. Furthermore, selection of lines among those of short cycle that have grain yield equivalent to the best normal cycle lines is of very low probability.
\end{abstract}

Keywords: Plant breeding, quantitative genetics, plant selection, early maturity.

\section{Introduction}

Even though the number of days from sowing to harvest (cycle) of the common bean (Phaseolus vulgaris) crop in Brazil, an average of 80 to 90 days, is shorter than most other annual species grown, there is still demand by farmers for cultivars with a shorter cycle. This demand arises for various reasons. The first is that an expressive area of the common bean crop is irrigated. Thus, the shorter the cycle, the lower the production costs, through reduction in the amount of water and energy spent on irrigation. A second reason is that common bean is normally part of a crop succession system with other crops. Thus, a shorter cycle allows greater flexibility in setting up the system, allowing three crops per year.

Various varietal groups are on the market in Brazil. However, the carioca (cream-colored seed coat with brown streaks) bean occupies the largest planted area. It was released on the Brazilian market at the end of the 1960s (Chiorato and Carbonell, 2014). Over these more than 50 years, most common bean breeding 
programs have devoted attention to this group, and numerous cultivars have been obtained with desirable phenotypes of traits important to farmers and consumers.

However, even recently, the question of cycle length has received less attention, one reason being that the shorter cycle cultivars that had been obtained had a determinate growth habit that nearly always had lower yield potential. In recent years, however, cultivars have been released with maturity earlier than that of existing cultivars and that have an indeterminate growth habit (Pereira et al., 2012; Melo et al., 2017). Nevertheless, the challenge remains, that is, the challenge of obtaining earlier maturity cultivars with grain yield equivalent to the yield of normal cycle cultivars. Some studies on common bean and other species indicate, as expected, that the correlation between grain yield and early maturity is negative (Iqbal et al., 2007; Yang et al., 2019; Guilherme et al., 2021). For that reason, the question arises as to what options there may be to mitigate this negative association.

One of the strategies to mitigate this negative association would be through reducing the period from sowing to flowering, without affecting the length of the grain filling period. Silva et al. (2007) showed that with few recurrent selection cycles, it was possible to have expressive gains in reducing the number of days to the beginning of flowering in common bean. This success mainly occurred because the trait has relatively high heritability. However, reduction in the total plant cycle was not observed because the genetic correlation between the number of days to the beginning of flowering and the number of days from sowing to harvest was of small magnitude (Silva et al., 2007).

It should be noted that for the rice crop, results showed that correlation between the beginning of flowering and grain yield depended on the climate conditions (Won et al., 2020). For most species, the beginning of flowering, though of high heritability, is highly affected by the environment, especially temperature and precipitation (Lizarazo et al., 2017). This environmental effect evidently must affect the number of days from sowing to harvest, and, consequently, success in obtaining cultivars with a foreseeable cycle.

Another strategy seeking to mitigate the negative association between grain yield and early maturity would be to obtain plants with greater efficiency in daily accumulation of dry matter in the grain. Thus, reduction in the cycle could be compensated due to this greater efficiency. Guilherme et al. (2021) used a diallel cross with 10 lines of common bean of different origins and showed that the genetic correlation between the duration of physiological maturity and daily accumulation of dry matter is negative. The authors report that none of the segregating populations was promising for selection of lines with early flowering and a long period of accumulation of dry matter in the grain. Thus, the results presented by Silva et al. (2007) are explained considering that flowering began earlier, yet it continued for a longer period; the length of the total crop cycle was not shorter.

Information not found in the literature is whether, from the same gene pool, it would be possible to obtain early maturity lines with grain yield equivalent to the yields of normal cycle lines coming from the same population. In addition, reports were not found of possible strategies for greater success in obtaining early maturity lines with indeterminate growth habit and carioca seed coat grain within the commercial standard. In light of the above, the aim of this study was to evaluate progenies differing in their cycle but coming from the same gene pool to determine if it is viable to select lines that have early maturity and that have grain yield equivalent to that of the best lines of normal cycle.

\section{Material and Methods}

The experiments were conducted in the Center of Scientific and Technological Development of the Universidade Federal de Lavras, state of Minas Gerais, Brazil, at 918 masl, 21 ${ }^{\circ} 58^{\prime}$ S and $42^{\circ} 22^{\prime}$ W.To obtain segregating populations in regard to crop cycle, crosses were made of normal or long cycle cultivars with carioca seed coat grain and indeterminate growth habit, BRSMG Madrepérola - M (Carneiro et al., 2011), Pérola 
- P (Yokoyama et al., 1999), and BRSMG UAI - U (Abreu et al., 2018) with the short cycle BRS FC104 - FC (Melo et al., 2017).

The crosses were carried out in a greenhouse in the Department of Biology of the Universidade Federal de Lavras. The $F_{1}$ seeds obtained were sown in February 2018 in the field to obtain seeds of the $F_{2}$ segregating population, which was sown in July 2018. In the $F_{2}$ segregating population, visual selection of the plants was performed, identifying the earlier maturity plants and those of normal or long cycle.

Beginning in November 2018, the $140 \mathrm{~F}_{2: 3}$ progenies of normal cycle and an equal number of short cycle progenies, involving the three populations, were multiplied. Once more, the longest cycle progenies were selected, obtaining 77 progenies, and the shortest cycle progenies were selected in the other group, also obtaining 77 progenies.

The $\mathrm{F}_{2: 4}$ progenies of normal cycle or short cycle were evaluated in February 2019 in different experiments. A $9 \times 9$ triple lattice design was used for each experiment, consisting of $77 \mathrm{~F}_{2: 4}$ progenies and the four parents as check cultivars. The $\mathrm{F}_{2: 5}$ progenies were evaluated once more, with sowing in July 2019, using the same design as the previous evaluation.

The plots of the experiments of evaluation of the $F_{2: 4}$ and $F_{2: 5}$ progenies consisted of two 2$\mathrm{m}$ rows with 30 plants per plot. In all the experiments, the between-row spacing was 0.5 $\mathrm{m}$. and 15 seeds were sown per linear meter. The experiments were irrigated, and the management practices adopted were similar to those recommended for the common bean crop in the region (Ramalho et al., 2014). The plants were not sprayed for control of pathogens and/or pests.

In all the experiments, the traits evaluated were grain yield in $\mathrm{kg} / \mathrm{ha}$, crop cycle in number of days after sowing up to harvest, and grain yield per day ( $\mathrm{kg} / \mathrm{ha} /$ day). The cycle was evaluated visually, considering the plot as suitable for harvest when approximately more than $90 \%$ of the plants had completely mature pods. Thus, the cycle was obtained, the period in days from the date of sowing up to the date of harvest.
Initially, as the experiments were well balanced, individual analysis of variance was performed on the data obtained per experiment. Combined analysis of variance of the early maturity and normal maturity experiments was also performed for each generation, using the check cultivars as regular treatments. After that, combined analysis of the two generations was carried out, using the adjusted means of the combined analyses, through the following model:

$$
y_{i j}=\mu+g_{i}+a_{j}+g a_{i j}+e_{i j}
$$

where $y_{i j}$ is the value observed of genotype $i$ in generation $j ; \mu$ is the overall mean of the experiment; $g_{i}$ is the effect of genotype $i$, with $i$ $=1,2,3, \ldots, q$, in which $q$ is the number of progenies and check cultivars evaluated, with $g_{i} \sim N\left(0, \sigma_{g}^{2}\right) ; a_{j}$ is the effect of generation $j$, with $a_{j} \sim N\left(0, \sigma_{a}^{2}\right) ; g a_{i j}$ is the effect of the interaction between genotype $I$ and generation $j$, with $g a_{i j} \sim N\left(0, \sigma_{g a}^{2}\right)$; and $e_{i j}$ is the experimental error associated with observation $y_{i j}$, with $e_{i j} \sim N\left(0, \sigma_{e}^{2}\right)$.

Climate data of the meteorological station at the Universidade Federal de Lavras, available in the Meteorological Database for Education and Research (Banco de Dados Meteorológicos para Ensino e Pesquisa - BDMEP) of the National Meteorological Institute (Instituto Nacional de Meteorologia - INMET), at "https://bdmep.inmet.gov.br", were collected for the period between the date of sowing and of harvest in each generation. Data included rainfall in $\mathrm{mm}(\mathrm{RN})$, maximum temperature in ${ }^{\circ} \mathrm{C}$ (TMAX), minimum temperature in ${ }^{\circ} \mathrm{C}$ (TMIN), mean compensated temperature in ${ }^{\circ} \mathrm{C}$ (TCOMP), solar irradiation in hours (SI), Piche evaporation in $\mathrm{mm}(\mathrm{EV})$, mean relative humidity in \% $(\mathrm{RH})$, and mean wind speed in mps (WS).

Multiple regression analyses were carried out using the cycle in days as the dependent variable $(\mathrm{Y})$ and the climatic variables as the independent variable (X). Regression analyses were also carried out using grain yield as the dependent variable (Y) and the cycle in days and the climatic variables as independent variable. First, all the progenies were considered in 
analysis and, after that, the progenies coming from each biparental cross $(\mathrm{M} \times \mathrm{FC}, \mathrm{P} \times \mathrm{FC}$, and $\mathrm{U} \times \mathrm{FC}$ ). The variables were selected by the stepwise procedure based on the Akaike information criterion (AIC) (Akaike, 1974).

All the analyses were performed in the $\mathrm{R}$ environment (R CORE TEAM, 2020) and the regression analyses were performed through the MASS package (Venables and Ripley, 2002).

\section{Results}

In general, in individual analyses of variance (data not shown), the effects of the progeny source of variation (SV) were significant $(p \leq 0.01)$. The accuracy estimates obtained, from $47 \%$ to $92 \%$, can be considered medium to high, indicating good experimental accuracy, a condition which is indispensable for inferences to be made from the results obtained.

The distributions of frequencies of the means of the progenies regarding the traits evaluated (Figure 1) confirm the difference between the progenies in both the early maturity experiment and the normal maturity experiment in the two generations evaluated, $F_{2: 4}$ and $F_{2: 5}$. The amplitude of variation for the cycle, in the mean of the progenies, was 19 days in the $F_{2: 4}$ generation. In the $\mathrm{F}_{2: 5}$ it was less, 14 days, though still an expressive value.

In the case of grain yield, the amplitude of variation was also expressive, both in $F_{2: 4}$ $(1876.5 \mathrm{~kg} / \mathrm{ha})$ and in $\mathrm{F}_{2: 5}(2132.3 \mathrm{~kg} / \mathrm{ha})$. However, the difference in terms of the response of the means of the progenies in the early or normal maturity experiment was not as evident as for the cycle. This was reflected in the estimate of the yield per day, in which a big overlap occurred in the performance of the progenies of the short or normal cycle.

Combined analyses of the two experiments were carried out for each generation, using the four check cultivars as regular treatments (analyses not shown). Significant differences ( $p$ $\leq 0.01$ ) were found for the experiments SV. That is, there were differences in the early and normal maturity experiments for the traits evaluated, except for the yield per day trait in the $F_{2: 4}$ generation. Such differences confirm that regarding the cycle, the progenies of the early maturity experiment exhibited a cycle in days significantly lower than the progenies of the normal maturity experiment. The same occurred for grain yield.

The estimates of heritability $\left(h^{2}\right)$ for selection in the mean of the progenies are noteworthy. For cycle, the $\mathrm{h}^{2}$ in $\mathrm{F}_{2: 4}$ was $78 \%$ and in $\mathrm{F}_{2: 5}, 76 \%$. The estimate of $\mathrm{h}^{2}$ for grain yield was $59.6 \%$ in $\mathrm{F}_{2: 4}$ and $19.4 \%$ in $\mathrm{F}_{2: 5}$ and for yield per day in $\mathrm{kg} / \mathrm{ha} /$ day, it was $59.5 \%$ in $\mathrm{F}_{2: 4}$ and $21.4 \%$ in $F_{2: 5}$. To check the effect of sowing time, sowing in February in $\mathrm{F}_{2: 4}$ and in July in $\mathrm{F}_{2: 5}$, and the interaction of the progenies with the time of sowing, combined analysis was performed (Table 1). Significant differences $(p \leq 0.01)$ were found for the generation/environment SV for the three traits.

Significant differences $(p \leq 0.01)$ were also observed for the genotype SV. In its decomposition, the $\mathrm{F}$ test was not significant only for the progeny vs check cultivar contrast. That is, the mean values of the progenies for the three traits were similar to the mean values of the parents. In the decomposition of the progeny SV, significant differences $(p \leq 0.01)$ were found for both early maturity and normal maturity, except for the yield per day trait in the normal maturity experiment. Notice also that the early maturity vs normal maturity contrast was significant $(\mathrm{p} \leq$ 0.01 ), indicating that the mean values of the early maturity and normal maturity progenies were different, as already mentioned. The SV of the genotype $\times$ generation interaction was significant $(p \leq 0.01)$ only for grain yield and yield per day. The interactions progeny $\times$ generation and check cultivar $\times$ generation were also significant $(p \leq$ 0.01 ) for the same traits.

To check for possible effects of the climate variables on grain yield and on cycle, multiple regressions were estimated (Table 2). In relation to grain yield, considering all the progenies, the climate variables that had the greatest effect were rainfall (RN) and minimum temperature (TMIN), as well as the plant cycle variable. Evaluation of the progenies coming from each biparental cross showed variation in the response of the climate variables selected. However, the cycle remained 
present in all the crosses, and represented $44.2 \%$ of the variation $\left(\mathrm{R}^{2}=44.2 \%\right)$.

In relation to the cycle as dependent variable and the climate variables as independent variables, a greater effect of the climate factors was observed, as is confirmed by the high estimates of $\mathrm{R}^{2}$.
This was mainly because most of the variables evaluated had an effect on variation of the cycle. Considering the progenies coming from each pair, there was little variation in the climate variables in the model. However, the RN variable exhibited the lowest AIC and thus exhibited the greatest effect on the crop cycle.

Figure 1. Distribution of the frequencies of the mean values of the progenies regarding cycle (days), grain yield $(\mathrm{kg} / \mathrm{ha})$, and yield per day $(\mathrm{kg} / \mathrm{ha} /$ day $)$. Data from evaluation of the experiments of the early and normal maturity progenies in the $\mathrm{F}_{2: 4}(\mathrm{~A})$ and $\mathrm{F}_{2: 5}(\mathrm{~B})$ generations.

A

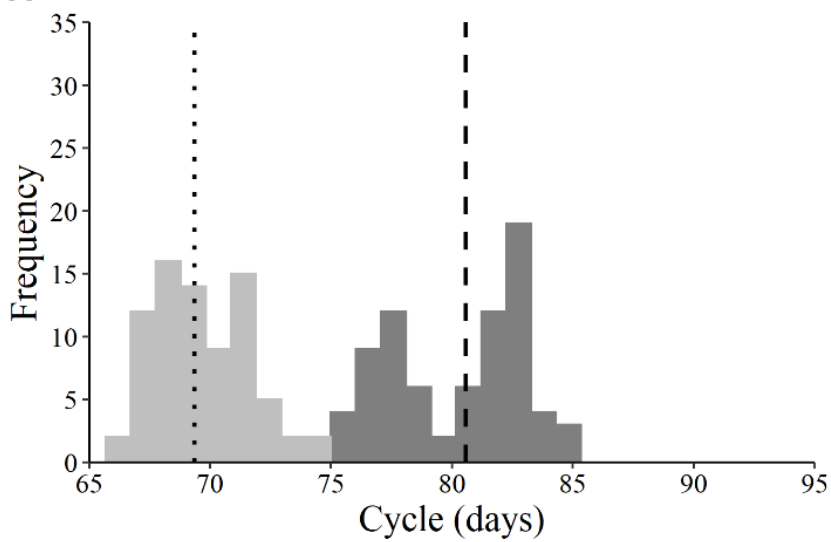

A

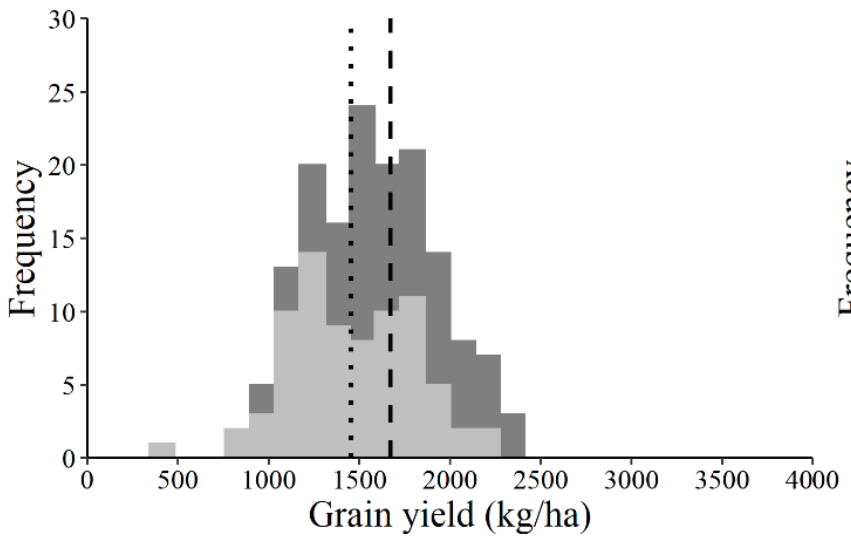

A

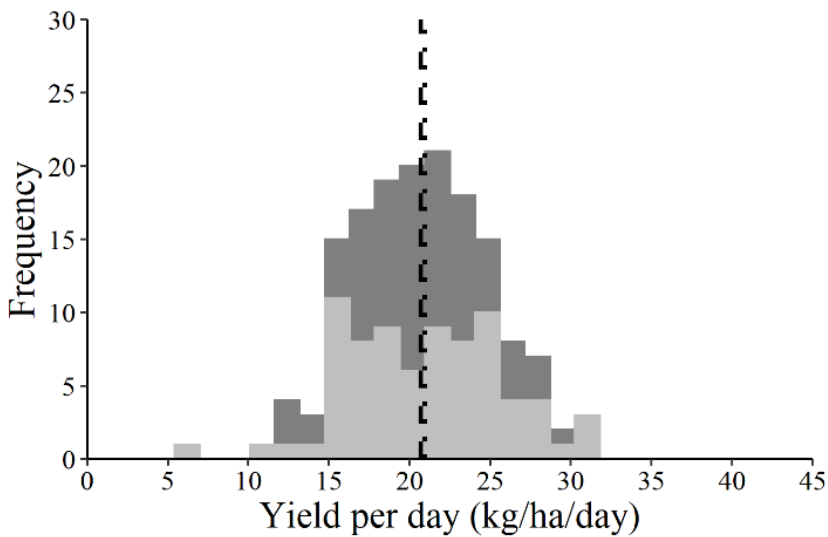

B
Early maturity progenies
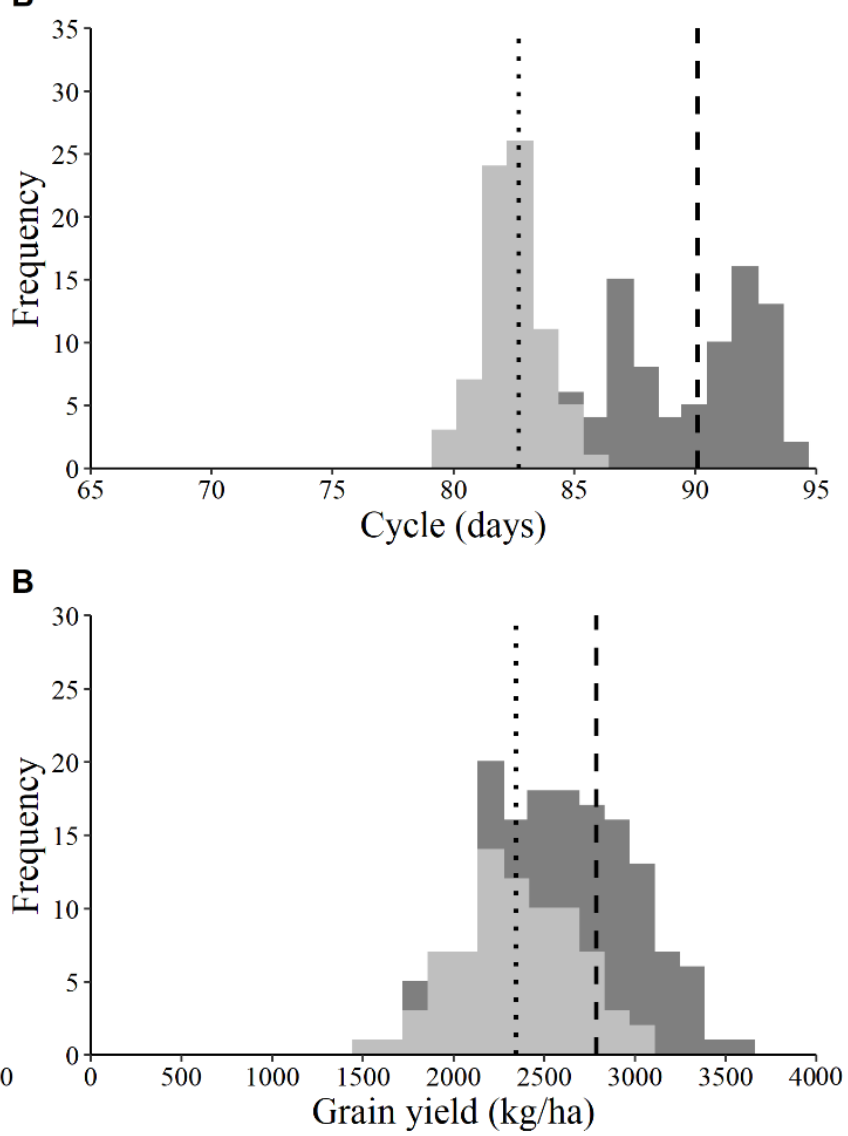

B

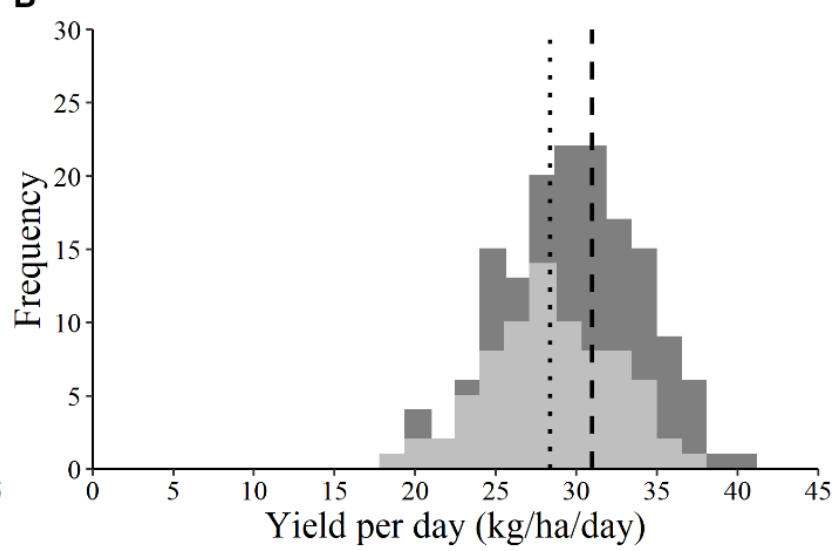


Table 1. Summary of the combined analyses of variance. Data obtained in the early and normal maturity experiments for the cycle (days), grain yield $(\mathrm{kg} / \mathrm{ha})$, and yield per day $(\mathrm{kg} / \mathrm{ha} /$ day) traits.

\begin{tabular}{|c|c|c|c|c|}
\hline \multirow{2}{*}{ sv } & \multirow{2}{*}{ DF } & \multicolumn{3}{|c|}{ MS } \\
\hline & & Cycle (days) & Yield (kg/ha) & $\begin{array}{l}\text { Yield per day } \\
\text { (kg/ha/day) }\end{array}$ \\
\hline Generations (A) & 1 & $31008.3^{\star \star}$ & $240036869.6^{* *}$ & $18803.1^{\star *}$ \\
\hline Genotypes (G) & 157 & $59.6^{\star *}$ & $515956.1^{* *}$ & $64.1^{* *}$ \\
\hline Progenies (P) & 153 & $58.4^{* *}$ & $513345.0^{* *}$ & $63.8^{* \star}$ \\
\hline Early maturity (E) & 76 & $11.0^{* *}$ & $384483.4^{* *}$ & $71.0^{* *}$ \\
\hline Normal maturity (N) & 76 & $35.9^{* *}$ & $320215.5^{\star *}$ & $37.9^{\text {ns }}$ \\
\hline E vs $\mathbf{N}$ & 1 & $5378.3^{* *}$ & $24984660 .{ }^{* *} 0$ & $1477.5^{* *}$ \\
\hline Check cultivars (C) & 3 & $137.1^{* *}$ & $809895.3^{* *}$ & $101.1^{*}$ \\
\hline P vs C & 1 & $1.5^{\mathrm{ns}}$ & $33629.0^{\mathrm{ns}}$ & $7.8^{\mathrm{ns}}$ \\
\hline$G \times A$ & 157 & $3.7^{\mathrm{ns}}$ & $349857.6^{* *}$ & $53.6^{* *}$ \\
\hline$P \times A$ & 153 & $3.3^{\mathrm{ns}}$ & $337128.3^{* *}$ & $51.9^{* *}$ \\
\hline$E \times A$ & 76 & $3.8^{\mathrm{ns}}$ & $267327.5^{\text {ns }}$ & $45.8^{* *}$ \\
\hline$N \times A$ & 76 & $2.7^{\mathrm{ns}}$ & $408072.3^{* *}$ & $56.6^{* *}$ \\
\hline$(E$ vs $N) \times A$ & 1 & $2.5^{\mathrm{ns}}$ & $250242.1^{\text {ns }}$ & $162.0^{*}$ \\
\hline$C \times A$ & 3 & $4.4^{\mathrm{ns}}$ & $952260.1^{* \star}$ & $142.6^{* *}$ \\
\hline$(P$ vs $C) \times A$ & 1 & $64.2^{* *}$ & $490228.2^{\text {ns }}$ & $40.1^{\mathrm{ns}}$ \\
\hline Residual & 652 & 3.3 & 211802.0 & 30.7 \\
\hline$h^{2}(\%)$ & & 94.3 & 34.3 & 18.7 \\
\hline
\end{tabular}

${ }^{* *},{ }^{*}$ and ${ }^{n s}$ : significant $(p \leq 0.01)$, significant $(p \leq 0.05)$, and not significant $(p>0.05)$ by the $F$ test, respectively.

Source of variation (SV), degrees of freedom (DF), mean square (MS) and heritability $\left(\mathrm{h}^{2}\right)$.

Table 2. Estimates of the coefficients of determination $\left(\mathrm{R}^{2}\right)$ and selected variables in the models through stepwise analysis ${ }^{1}$ based on the Akaike Hoking information criterion (AIC).

\begin{tabular}{rlrl}
\hline $\begin{array}{c}\text { Dependent } \\
\text { variable }(\mathrm{Y})\end{array}$ & Progenies & $\mathbf{R}^{\mathbf{2}}(\mathbf{\%})$ & Variables in the model \\
\hline \multirow{3}{*}{ Yield } & All & 53.0 & $\mathrm{RN}+$ Cycle + TMIN \\
\cline { 2 - 4 } & $\mathrm{M} \times \mathrm{FC}$ & 56.2 & $\mathrm{SI}+$ Cycle \\
\cline { 2 - 4 } & $\mathrm{P} \times \mathrm{FC}$ & 57.3 & $\mathrm{EV}+\mathrm{TMIN}+$ Cycle \\
\cline { 2 - 4 } Cycle & $\mathrm{U} \times \mathrm{FC}$ & 52.3 & $\mathrm{Cycle}+\mathrm{TMAX}$ \\
\cline { 2 - 4 } & $\mathrm{All}$ & 95.0 & $\mathrm{RN}+\mathrm{WS}+\mathrm{EV}+\mathrm{RH}+\mathrm{SI}+\mathrm{TMAX}+\mathrm{TCOMP}$ \\
\cline { 2 - 4 } & $\mathrm{M} \times \mathrm{FC}$ & 97.5 & $\mathrm{RN}+\mathrm{WS}+\mathrm{EV}+\mathrm{TCOMP}+\mathrm{TMIN}+\mathrm{TMAX}+\mathrm{RH}+\mathrm{SI}$ \\
& $\mathrm{P} \times \mathrm{FC}$ & 97.2 & $\mathrm{RN}+\mathrm{WS}+\mathrm{SI}+\mathrm{TMAX}+\mathrm{TCOMP}+\mathrm{TMIN}+\mathrm{RH}$ \\
\cline { 2 - 3 } & $\mathrm{U} \times \mathrm{FC}$ & 95.3 & $\mathrm{RN}+\mathrm{TCOMP}+\mathrm{WS}+\mathrm{EV}+\mathrm{SI}+\mathrm{RH}+\mathrm{TMAX}$ \\
\hline
\end{tabular}

${ }^{1}$ Stepwise analysis based on the Akaike Hoking (1974) information criterion (AIC).

BRSMG Madrepérola (M), Pérola (P), BRSMG UAI (U), BRS FC - 104 (FC), grains yield in $\mathrm{kg} / \mathrm{ha}$ (Yield), crop cycle in number of days after sowing up to harvest (Cycle), rainfall in $\mathrm{mm}(\mathrm{RN})$, maximum temperature in ${ }^{\circ} \mathrm{C}(\mathrm{TMAX})$, minimum temperature in ${ }^{\circ} \mathrm{C}(\mathrm{TMIN})$, mean compensated temperature in ${ }^{\circ} \mathrm{C}$ (TCOMP), solar irradiation in hours (SI), Piche evaporation in $\mathrm{mm}(\mathrm{EV})$, mean relative humidity in \% (RH), and mean wind speed in mps (WS).

In general, the progenies of the early maturity experiment, on average, had a shorter cycle, and lower grain yield and yield per day. They showed a reduction of approximately $15 \%$ for grain yield and $10 \%$ for yield per day, in relation to those of the normal cycle experiment. Reduction in the cycle was five days in relation to the progenies of the normal maturity experiment, that is, $6 \%$ in relation to the mean. Note also that the difference in the cycle of the early maturity progenies in relation to the normal progenies was similar to the difference between the early maturity parent and the mean of the other three parents considered as having a normal cycle (Table 3 ). 
The five highest yielding progenies of each biparental cross were identified (Table 4). The highest yielding progeny $(2826.7 \mathrm{~kg} / \mathrm{ha})$ came from the $\mathrm{P} \times \mathrm{FC}$ cross, and its cycle was 81 days. The progeny with the highest yield among those of early maturity $(2412.2 \mathrm{~kg} / \mathrm{ha}$ from the $\mathrm{M} \times \mathrm{FC}$ cross) was $15 \%$ lower than the highest yielding of the normal cycle progenies. This yield of the early maturity progeny was obtained with only three days difference in the cycle in relation to the normal cycle. Reduction in grain production of the earliest maturity progeny, five days difference in the cycle $(2289.9 \mathrm{~kg} / \mathrm{ha}$ of the $\mathrm{P} \times$ FC cross), was $19 \%$.

Table 3. Mean values of the progenies and check cultivars, considering the mean values of the $F_{2: 4}$ and $F_{2: 5}$ generations for the cycle (days), grain yield ( $\mathrm{kg} / \mathrm{ha})$, and yield per day $(\mathrm{kg} / \mathrm{ha} /$ day) traits.

\begin{tabular}{lccc}
\hline & Cycle (days) & Yield (kg/ha) & $\begin{array}{c}\text { Yield per day } \\
\text { (kg/ha/day) }\end{array}$ \\
\hline Early progenies & 78 & 1900.9 & 24.0 \\
\hline Normal progenies & 83 & 2229.8 & 26.5 \\
\hline Check cultivar (FC) & 78 & 2214.3 & 28.0 \\
\hline Check cultivars (M, P, and U) & 82 & 2051.9 & 24.9 \\
\hline
\end{tabular}

BRSMG Madrepérola (M), Pérola (P), BRSMG UAI (U), and BRS FC - 104 (FC).

Table 4. Mean values of the five progenies with highest grain yield $(\mathrm{kg} / \mathrm{ha})$ for each biparental cross in the early maturity and normal maturity experiments.

\begin{tabular}{|c|c|c|c|c|}
\hline \multirow{2}{*}{ Biparental cross } & \multicolumn{2}{|c|}{ Early } & \multicolumn{2}{|c|}{ Normal } \\
\hline & Cycle (days) & Yield (kg/ha) & Cycle (days) & Yield (kg/ha) \\
\hline \multirow{5}{*}{$M \times F C$} & 78 & 2412.2 & 80 & 2379.2 \\
\hline & 79 & 2255.1 & 80 & 2363.9 \\
\hline & 77 & 2206.5 & 79 & 2295.8 \\
\hline & 77 & 2095.3 & 81 & 2265.2 \\
\hline & 77 & 2054.9 & 81 & 2199.8 \\
\hline \multirow{5}{*}{$P \times F C$} & 77 & 2353.8 & 81 & 2826.7 \\
\hline & 80 & 2312.1 & 81 & 2577.9 \\
\hline & 76 & 2289.9 & 84 & 2498.7 \\
\hline & 78 & 2216.2 & 80 & 2320.8 \\
\hline & 78 & 2212.0 & 81 & 2283.2 \\
\hline \multirow{5}{*}{$\mathbf{U} \times \mathbf{F C}$} & 79 & 2267.6 & 85 & 2608.5 \\
\hline & 79 & 2088.3 & 86 & 2573.8 \\
\hline & 79 & 2084.1 & 86 & 2558.5 \\
\hline & 80 & 2041.0 & 85 & 2558.5 \\
\hline & 79 & 2020.2 & 85 & 2554.3 \\
\hline
\end{tabular}

Progenies originated from the biparental crosse between BRSMG Madrepérola and BRS FC - 104 (M $\times$ FC), Pérola and BRS FC - 104 $(\mathrm{P} \times \mathrm{FC})$, and BRSMG UAI and BRS FC - $104(\mathrm{U} \times \mathrm{FC})$.

\section{Discussion}

If the progenies of early and normal cycle were evaluated together, staggered harvest of the plants would certainly require more frequent movement within the experiment, hurting experimental accuracy. To avoid this, the early maturity and normal maturity progenies were evaluated in different experiments.
The estimates of the accuracies obtained for both conditions can be considered medium to high (Resende and Duarte, 2007), which confirmed that the procedure adopted was correct. In evaluation of plants in the field experiment, the period of maturation of the two groups was visually quite evident, that is, the experiment that had early cycle progenies and normal cycle progenies. Thus, evaluation of the 
progenies in separate experiments meant that accuracy would not be hurt.

It should also be mentioned initially that evaluation of the plant/line cycle based on beginning of flowering is common (González et al., 2016; Manning et al., 2020). However, the duration of flowering varies among the lines. In addition, flower set depends on environmental conditions and, normally, greater setting occurs in the first flowers (Martins et al., 2017). However, if the environmental conditions are not favorable at the beginning of flowering, flower set does not occur, and the flowers that would set would be at the end of flowering, prolonging the cycle. Likewise in lentils (Lens culinares Medik.), Bueckert et al. (2020) showed that the first flowers are most important for grain yield; however, when environmental conditions are unfavorable at the beginning of flowering, the flowers that emerge later increase in importance for yield. In other words, the prolonged flowering period allows plants to have greater plasticity to adjust to climate variations.

In light of the above, evaluating the cycle by the beginning of flowering does not always provide information compatible with the effective duration of the cycle. This was confirmed in a study by Silva et al. (2007), in which a smaller number of days from sowing to maturity due to the smaller number of days to the beginning of flowering was expected; however, a reduction in the plant cycle was not observed. The authors affirm that an association between the total cycle and the number of days to flowering was not found; the genetic correlation between these traits was practically null.

For that reason, in this study, the option was made to evaluate through observation of the plants that were able to be harvested, that is, when the pods of the plants were already changing color, indicating complete maturity. It should be emphasized that as all the parents used in the hybridizations have carioca seed coat grain, complete physiological maturity of the grain occurs at the time streaks appear, a characteristic of this varietal group (Vieira and Vieira, 1997; Guilherme et al., 2021). That moment coincides with the change in color of the pods and, in certain cases, streaks also appear on the pods. The same procedure for evaluation of the cycle based on the number of days from sowing to maturity was performed by Gesteira et al. (2018) in the soybean crop.

The difference regarding the cycle of the progenies is quite explicit in Figure 1, as was expected as a result of the differences in the cycle of the parents involved in the hybridizations (Yokoyama et al., 1999; Carneiro et al., 2011; Melo et al., 2017; Abreu et al., 2018). The difference in the cycle between the early maturity and normal maturity progenies was also evident, indicating that the visual selections made among $F_{2}$ plants and $F_{2: 3}$ progenies were efficient. The $\mathrm{h}^{2}$ estimates were the reasons for success in visual selection made and that was highlighted in Figure 1. In the literature, reports show that early selection, performed visually, is effective when the $\mathrm{h}^{2}$ of the trait is high (Ramalho et al., 2012b).

According to Bernardo (2014), the effectiveness of early selection depends on the correlation between the phenotype of the progeny $\left(P_{i}\right)$ in the generation of evaluation and the genotype $\left(G_{j}\right)$ in a more advanced generation $\left(r_{P_{i} G_{j}}\right)$, obtained by the following expression:

$$
r_{P_{i} G_{j}}=r_{G_{i} G_{j}} \sqrt{h_{i}^{2}}
$$

where $h_{i}^{2}$ is the heritability of the trait in the generation of evaluation $i$, and $r_{G_{i} G_{j}}$ is the genetic correlation between the progenies in the $i$ and $j$ generations. This correlation is a result only of the inbreeding coefficient in the generations considered, that is

$$
r_{G_{i} G_{j}}=\sqrt{\left(1+I_{i}\right) /\left(1+I_{j}\right)} .
$$

In the present case, considering the $\mathrm{F}_{2: 3}$ of selection and $F_{2: 4}$ of evaluation, the value of the correlation coefficient is 0.93 , a value of high magnitude, and that frequently occurs.

The $F_{2: 5}$ generation, sown in July, had higher mean values for cycle, grain yield, and yield per day. That occurred because in the region at that time, temperatures are milder and, 
especially up to near flowering, relative humidity is low, which contributes to lower incidence of pathogens in relation to sowing carried out in February. Indeed, this was observed in the $F_{2: 4}$ generation through the extensive occurrence of angular leaf spot and especially bacterial blight, favored by higher temperature and relative humidity. These results are frequently observed in other studies conducted in the region (Arantes et al., 2010; Pinto Júnior et al., 2018).

The variation observed among the generations involves not only the genetic question but also the environmental effect, because the experiments were conducted at different times. The genetic effect between the $\mathrm{F}_{4}$ and $\mathrm{F}_{5}$ generations is a consequence of inbreeding. It should be considered that the possible effect of inbreeding depends on the proportion of loci in heterozygosity in the previous generation and on whether the trait is dominant. That is because in $\mathrm{F}_{4}$, only $1 / 8$ of the loci were in heterozygosity, that is, reduction in the frequency of the loci in heterozygosity from one generation to another is small. Thus, the effect of the generation must predominantly be due to the difference in environmental conditions of the evaluation times.

The fact that the progeny vs check cultivar contrast was not significant (Table 1) indicates that the means of the progenies for the three traits evaluated were similar to the means of the parents. These results, in principle, lead to the inference that the additive allelic interaction is predominant in genetic control of these traits (Ramalho et al., 2012a). Various other reports indicate that the additive allelic interaction is common in autogamous plants (Novoselovic et al., 2004; Moreto et al., 2007). The significant interactions for progenies $\times$ generations and check cultivars $\times$ generations for the grain yield and yield per day traits show that the performance of the progenies did not coincide in the two generations. This result is common in studies performed on common bean in the region (Ferreira et al., 2015; Lima et al., 2013). The existence of the interaction is important; however, it is not possible to identify a specific cultivar for each time period or environment.
Thus, the alternative is to use mean values for better representation of the future.

As previously reported, for the cycle trait, a high estimate of $\mathrm{h}^{2}, 94.3 \%$, was observed for selection in the mean of the progenies in the two generations (Table 1). In a study by Silva et al. (2007), high estimates of $h^{2}$ were also observed for the trait of number of days to the beginning of flowering; the estimates ranged from $79.2 \%$ to $93.1 \%$. As the dominance variance $\left(\sigma_{D}^{2}\right)$ for the cycle trait should be small and, additionally, among $\mathrm{F}_{2: 4}$ progenies only $1 / 16$ of $\sigma_{D}^{2}$ is exploited and $1 / 64$ is exploited in $F_{2: 5}$ (Ramalho al., 2012b), thus $\mathrm{h}^{2}$ can be considered in the narrow sense.

The $\mathrm{h}^{2}$ estimates for selection in the mean of the progenies considering the two generations for grain yield were $34.3 \%$ and $18.7 \%$ for the yield per day trait (Table 1). There are numerous reports in the literature of $h^{2}$ estimates for selection in the mean of progenies for grain yield. In a survey by Ramalho et al. (2012b) of ten data in the literature, the estimates ranged from $10.6 \%$ to $88.0 \%$. Unfortunately, no report of the $h^{2}$ estimate for the yield per day was found.

Through the results obtained in multiple regressions, upon considering grain yield as dependent variable (Y), cycle was selected among the independent variables $(\mathrm{X})$ in the models in all the situations, emphasizing that its importance for grain yield occurred in all the biparental crosses. Upon considering cycle as the dependent variable $(\mathrm{Y})$, rainfall was the climate variable that had the greatest effect, for all the progenies. The importance of water availability and/or rainfall for grain yield is commonly reported in the literature (Carvalho et al., 2018; Durigon et al., 2019) and one of the reasons must be by indirect effect on the crop cycle.

In general, the difference regarding the cycle of the early maturity progenies in relation to the normal maturity progenies was five days. In principle, this value may appear small. However, from the perspective of intensive agriculture, reduction of five days in the cycle can facilitate the crop succession system. In addition, if the crop is irrigated, this will evidently reduce production costs. According to Melo et al. (2017), the early 
maturity parent BRS FC104 evaluated in various environments had a very short cycle, approximately 65 days. However, the authors conducted the experiments under different edaphic and climatic conditions, above all under temperatures normally superior to those observed while conducting experiments in the $\mathrm{F}_{2: 4}$ and $\mathrm{F}_{2: 5}$ generations. Moreover, the authors argued that crop cycle is highly dependent on climate conditions, as was likewise shown in this study.

A study conducted on the rice crop in the Philippines (Won et al., 2020) showed the possibility of obtaining early maturity lines with grain yield equivalent or even superior to the yield of the normal cycle line recommended for the region. However, the authors emphasized that the plants of those lines had expressive phenotypic changes for some traits, such as leaf width and plant height, which contributed to greater biomass and, consequently, higher grain yield.

Finally, considering the same gene pool (the same segregating population) used in this study, the question arises as to whether it would be possible to select an early maturity progeny with grain yield equal to that of the highest yielding progeny among those of normal cycle. That is, would it be possible to select a progeny with a short cycle and yield of $2827 \mathrm{~kg} / \mathrm{ha}$ in the same population?

The first alternative would be through evaluation of a larger number of early maturity progenies. However, how many would that be? Considering the early maturity progenies of this study, the estimate of genetic variance $\left(\sigma_{g}^{2}\right)$, disregarding the interaction, was 19526.0, that is, a genetic standard deviation $\left(\sigma_{g}\right)$ of 139.7. From the properties of a normal distribution with mean grain yield equal to that obtained in evaluation of the early maturity progenies, what would the size of the population be to have an early maturity progeny with a mean grain yield of $2827 \mathrm{~kg} / \mathrm{ha}$ ? As the standard deviation was 139.7 and the mean yield of the early maturity progenies was $1901 \mathrm{~kg} / \mathrm{ha}$, the extreme value $(2827 \mathrm{~kg} / \mathrm{ha})$ of the normal distribution would be 6.63 deviations above the mean (2827-1901/139.7). Thus, the amplitude of variation of the normal distribution would be $2 \times 6.63$ deviations, that is, 13.26 deviations. Under these conditions, more than 100,000 progenies being evaluated would be necessary to achieve the goal (Steel et al., 1997).

The second alternative would be through a recurrent selection (RS) program in which the early maturity plants would be selected in the $\mathrm{S}_{0}$ generation and then evaluated for grain yield in $\mathrm{S}_{0: 1}$ and $\mathrm{S}_{0: 2}$ progenies. The highest yielding would be recombined. Thus, it is expected that after some cycles of recombination and selection, early maturity progenies with good grain yield would be obtained. Unfortunately, no report of use of RS for that purpose was found.

\section{Conclusion}

The early maturity progenies coming from the same gene pool as the normal cycle progenies exhibited a $15 \%$ reduction in grain yield and $10 \%$ reduction in yield per day. Aiming to obtain early maturity progenies with grain yield equivalent to the highest yielding progeny of the normal cycle, the number of early maturity progenies necessary for evaluation is practically unviable.

\section{Acknowledgments}

The authors are grateful to Coordenação de Aperfeiçoamento de Pessoal de Nível Superior (CAPES) - Financial Code 001, and to Conselho Nacional de Desenvolvimento Científico e Tecnológico (CNPq) for the funding support.

\section{References}

ABREU, A.F.B.; RAMALHO, M.A.P.; CARNEIRO, J.E.D.S.; MELO, L.C.; PEREIRA, H.S.; de SOUZA, T.L.P.O; de PAULA JÚNIOR, T.J.; de SOUZA, E.A.; PEREIRA FILHO, I.A.; MARTINS, M.; Del GIÚDICE, M.P.; VIEIRA, R.F. 2018. BRSMG UAI: cultivar de feijão tipo carioca com planta de arquitetura ereta. Embrapa Arroz e Feijão - Comunicado Técnico (INFOTECA-E). 
AKAIKE, H., 1974. A new look at the statistical model identification. IEEE Transactions on Automatic Control, 19(6):716-723.

ARANTES, L.O.; ABREU, A.F.B.; RAMALHO, M.A.P. 2010. Eight cycles of recurrent selection for resistance to angular leaf spot in common bean. Crop Breeding and Applied Biotechnology, 10(3):232-237.

BERNARDO, R. 2014. Essentials of plant breeding. Editora Stemma Press, Ed.1, Minnesota.

BUECKERT, R.; ZAKERI, H.; PRITCHARD, J.; LAFOND, G. 2020. First versus last born: Flowers, pods, and yield formation in no-tillage lentil. Crop Science, 60:1634-1647.

CARNEIRO, J.D.S.; ABREU, A.D.F.B; RAMALHO, M.A.P.; DEL PELOSO, M.J.; DE PAULA JÚNIOR, T.J.; VIEIRA, R.F.; TEIXEIRA, H.; PEREIRA FILHO, I.A.; MARTINS, M.; DE FARIA, L.C.; MELO, L.C.; PEREIRA, H.S.; DOS SANTOS, J.B.; DA COSTA, J.G.C.; DE FARIA, J.C.; CARNEIRO, P.C.S 2011. BRSMG Madrepérola: cultivar de feijão tipo carioca com escurecimento tardio dos grãos. Embrapa Arroz e Feijão-Artigo em Anais de congresso (ALICE).

CARVALHO, J.J.; SAAD, J.C.C.; TEIXEIRA, M.B.; SOARES, F.A.L.; DA SILVA, N.F.; DI CAMPOS, M.S.; CUNHA, F.N; DOS SANTOS, L.N.S. 2018. Effects of deficit irrigation on the productivity of the common bean (Phaseolus vulgaris L.). Agriculture Engineering International, 20(3):24-34.

CHIORATO, A.F.; CARBONELL, S.A.M. 2014. O Melhoramento Genético do Feijoeiro no Instituto Agronômico IAC (1932 a 2014). O Agronômico, 64:6-13.

DURIGON, A.; EVERS, J.; METSELAAR, K.; VAN LIER, Q.J. 2019. Water stress permanently alters shoot architecture in common bean plants. Agronomy, 9(160):1-22.

GESTEIRA, G.D.S.; BRUZI, A.T.; ZITO, R.K.; FRONZA, V.; ARANTES, N.E. 2018. Selection of Early Soybean Inbred Lines Using Multiple Indices. Crop Science, 58(6):2494-2502.

FERREIRA, R.A.D.C.; RAMALHO, M.A.P.; TOLEDO, F.H.R.B.; ABREU, A.D.F.B. 2015. Implications of the number of years assessment on recommendation of common bean cultivars. Plant Breeding, 134(5):599-604.

GONZÁLEZ, A.M.; YUSTE-LISBONA, F.J.; SABURIDO, S.; BRETONES, S.; DE RON, A.M.; LOZANO, R.; SANTALLA, M. 2016. Major contribution of flowering time and vegetative growth to plant production in common bean as deduced from a comparative genetic mapping. Frontiers in Plant Science, 7(1940):1-18.

GUILHERME, S.R.; ABREU, A.F.B.; DA SILVA, R.R.; RAMALHO, M.A.P. 2021. Genetic control of traits related to grain filling in common bean. Genetics and Molecular Research, 20(1):112.

IQBAL, M.; NAVABI, A.; SALMON, D.F.; YANG, R.C.; SPANER, D. 2007. Simultaneous selection for early maturity, increased grain yield and elevated grain protein content in spring wheat. Plant Breeding, 126(3):244-250.

LIMA, L.K.D.; RAMALHO, M.A.P.; ABREU, A.D.F.B. 2013. Selection of common bean inbred lines with tolerance to high moisture at harvest. Ciência e Agrotecnologia, 37(2):152-158. 
LIZARAZO, C.I.; ISOTALO, J.; LINDFORS, A.V.; STODDARD, F.L. 2017. Progress towards flowering of faba bean (Vicia faba L.) is more than photothermal. Journal of Agronomy and Crop Science, 203(5):385-396.

MANNING, B.K.; ADHIKARI, K.N.; TRETHOWAN, R. 2020. Impact of sowing time, genotype, environment and maturity on biomass and yield components in faba bean (Vicia faba). Crop and Pasture Science, 71(2):147-154.

MARTINS, E.S.; PINTO JUNIOR, R.A.; ABREU, A.D.F.B.; RAMALHO, M.A.P. 2017. Genetic control of number of flowers and pod set in common bean. Genetics and Molecular Research, 16(3):1-14.

MELO, L.C.; PEREIRA, H.S.; DE SOUZA, T.L.P.O.; de FARIA, L.C.; DE AGUIAR, M.S.; WENDLAND, A.; DE CARVALHO, H.W.L.; DE ALMEIDA, V.M.; DE MELO, C.L.P.; DA COSTA, A.F.; ITO, M.A.; PEREIRA FILHO, I.A.; POSSE, S.C.P.; MAGALDI, M.C.S.; DÍAZ, J.L.C.; DA COSTA, J.G.C.; ABREU, A.F.B.A.; MARTINS, M.; GUIMARÃES, C.M.; TRINDADE, N.L.S.R.; MELHO, P.G.S.; BRAZ, A.J.B.P.; DE SOUZA, N.P.; DE FARIA, J.C. 2017. BRS FC104: Cultivar de feijão comum carioca super-precoce. Embrapa Arroz e Feijão - Comunicado Técnico (INFOTECA-E).

MORETO, A.L.; RAMALHO, M.A.P.; NUNES, J.A.R.; ABREU, A.F.B.A. 2007. Estimação dos componentes da variância fenotípica em feijoeiro utilizando o método genealógico. Ciência e Agrotecnologia, 31(4):1035-1042.

NOVOSELOVIC, D.; BARIC, M.; DREZNER, G.; GUNJACA, J.; LALIC, A. 2004. Quantitative inheritance of some wheat plant traits. Genetics and Molecular Biology, 27(1):92-98.

PEREIRA, H.S.; WENDLAND, A.; MELO, L.C.; DEL PELOSO, M.J.; DE FARIA, L.C.; NASCENTE, A.; DIAZ, J.L.C; DA COSTA, A.F.; DE ALMEIDA, V.M.; DE MELO, C.L.P.; MAGALDI, M.C.S.; ABREU, A.F.B.; MOREIRA, J.A.A.; PEREIRA FILHO, I.A.; CARGNIN, A.; POSSE, S.C.P.; DE SOUZA FILHO, B.F.; DE MOURA NETO, F.P.; SOUZA, J.F.; GUIMARÃES, C.M.; BRAZ, A.J.B.P.; FERREIRA, S.B.; MARANGON, M.A.; DE SOUZA, N.P.; DE OLIVEIRA, J.P.; DE FARIA, J.C.; BASSINELLO, P.Z.; VIANELLO, R.P. 2012. BRS Notável - Cultivar de feijoeiro comum carioca semiprecoce com alto potencial produtivo e resistência a doenças. Embrapa Arroz e Feijão - Comunicado Técnico (INFOTECA-E).

PINTO JÚNIOR, R.A.; RAMALHO, M.A.P.; MARTINS, E.S.; ABREU, A.F.B. 2018. Inheritance of harvest index in common bean. Crop Breeding and Applied Biotechnology, 18(3):252258.

$\mathrm{R}$ Core Team 2020. A language and environment for statistical computing. $\mathrm{R}$ Foundation for Statistical Computing, Vienna, Austria.

RAMALHO, M.A.P.; ABREU, A.F.B.; GUILHERME, S.R. 2014. Informações técnicas para o cultivo do feijoeiro-comum na região Central-Brasileira: 2015-2017. Anais da 20a Reunião da Comissão Técnica Central Brasileira de Feijão.

RAMALHO, M.A.P.; DOS SANTOS, J.B.; PINTO, C.A.B.P.; DE SOUZA, E.A.; GONÇALVES, F.M.A.; DE SOUZA, J.C. 2012a. Genética na agropecuária. Editora UFLA, Ed.5, Lavras.

RAMALHO, M.A.P; ABREU, A.F.B.; DOS SANTOS, J.B.; NUNES, J.A.R. 2012b. Aplicações da genética quantitativa no melhoramento de plantas. Editora UFLA, Ed.1, Lavras. 
RESENDE, M.D.V.; DUARTE, J.B. 2007. Precisão e controle de qualidade em experimentos de avaliação de cultivares. Embrapa Florestas-Artigo em Periódico Indexado (ALICE).

SILVA, F.B.; RAMALHO, M.A.P.; ABREU, A.F.B. 2007. Seleção recorrente fenotípica para florescimento precoce de feijoeiro 'Carioca'. Pesquisa Agropecuária Brasileira, 42(10):14371442.

STEEL, R.G.D.; TORRIE, J.H.; DICKEY, D.A. 1997. Principles and procedures of statistics: a biometrical approach. Editora McGraw-Hill, Ed.3, New York.

VENABLES, W.N.; RIPLEY, B.D. 2002. Modern Applied Statistics with S. Editora Springer, Ed.4, New York.

WON, P.L.P.; LIU, H.; BANAYO, N.P.M.; NIE, L.; PENG, S.; ISLAM, M.R.; CRUZ, P.S.; COLLARD, B.C.Y.; KATO, Y. 2020. Identification and characterization of high-yielding, short-duration rice genotypes for tropical Asia. Crop Science, 60(5):2241-2250.

YANG, J.; LI, Y.; CAO, H.; YAO, H.; HAN, W.; SUN, S. 2019. Yield-Maturity Relationships of Summer Maize from 2003 to 2017 in the Huanghuaihai plain of china. Scientific Reports, $9(1): 1-11$

YOKOYAMA, L.P.; DEL PELOSO, M.J.; DI STEFANO, J.G.; YOKOYAMA, M. 1999. Nível de aceitabilidade da cultivar de feijão "Pérola". Embrapa Arroz e Feijão - Comunicado Técnico (INFOTECA-E). 